九州大学学術情報リポジトリ

Kyushu University Institutional Repository

\title{
Effects of 1,5-Disubstituted Imidazoles on the Growth of Lettuce and Rice Seedlings
}

Kikuchi, Masamichi

Laboratory of Pesticide Chemistry, Faculty of Agriculture, Kyushu University

Kuwano, Ei ichi

Laboratory of Pesticide Chemistry, Faculty of Agriculture, Kyushu University

Nakashima, Yukiko

Laboratory of Pesticide Chemistry, Faculty of Agriculture, Kyushu University

Eto, Morifusa

Laboratory of Pesticide Chemistry, Faculty of Agriculture, Kyushu University

https://doi.org/10.5109/23972

出版情報: 九州大学大学院農学研究院紀要. 36 (1/2)，pp.83-92，1991-10. Kyushu University バージョン：

権利関係 : 


\title{
Effects of 1,5-Disubstituted Imidazoles on the Growth of Lettuce and Rice Seedlings
}

\author{
Masamichi Kikuchi, Eiichi Kuwano, Yukiko Nakashima \\ and Morifusa Eto \\ Laboratory of Pesticide Chemistry, Faculty of Agriculture, \\ Kyushu University 46-02, Fukuoka 812 \\ (Received July 16, 1991)
}

\begin{abstract}
Twenty two 1,5-disubstituted imidazoles possessing a phenyl, 4-hydroxyphenyl or 4methoxyphenyl group at the 5-position were synthesized and their plant growth regulatory activities were examined by the lettuce and rice seedling tests. Most of the compounds inhibited the hypocotyl growth of lettuce seedlings at $10 \mathrm{ppm}$. Among the compounds tested, 1-buty1-5-(4-methoxyphenyl)imidazole (20) and the 1-cyclohexylmethyl analog 25 showed the highest activity. 1,5-Disubstituted imidazoles described in this article had little or no effect on the growth of the shoot of rice seedlings at low concentrations, while a number of compounds remarkably enhanced the elongation of rice roots. Administration of $0.1-1 \mathrm{ppm}$ of compound 20 accelerated the root elongation, the values being more than $150 \%$ of the control.
\end{abstract}

\section{INTRODUCTION}

In a previous paper we reported that some 5-substituted1-neopentylimidazoles inhibited the growth of hypocotyls in the lettuce seedlings, and their activities were annulled fully by simultaneous application of gibberellic acid (GA,), suggesting an inhibition of gibberellin biosynthesis (Kikuchi $\notin$ d., 1990). In the lettuce seedling tests it was also found that some of 1-alkyl-5-arylimidazoles stimulated the growth of roots. It is well known that several 1,2,4-triazole, pyrimidine and pyridine derivatives inhibit the gibberellin biosynthesis and show plant growth regulatory activity resulting in growth retardation (Burden $\notin$ d., 1989). However, little information has been reported on the activity of promoting root growth. We therefore synthesized a new series of 1,5-disubstituted imidazoles and examined their effects on the growth of lettuce and rice seedlings. This report describes the synthesis of 1,5-disubstituted imidazoles and their activities to inhibit the growth of lettuce hypocotyls and to promote the root growth in rice seedlings.

\section{EXPERIMENTAL}

\section{Synthesis}

All melting points were uncorrected. ${ }^{1} \mathrm{H}$ NMR spectra were determined on a JEOL JNM-FX 100 spectrometer using tetramethylsilane as an internal standard, and all samples were prepared in $\mathrm{CDCl}_{3}$ unless otherwise noted.

$N$-( $\alpha$-tosylstyryl)formamide (1) and 1-isocyano-2-phenylll-tosylethene (2) were prepared according to the method described by van Leusen et d. $(1977,1979)$. 
Scheme 1

(A)
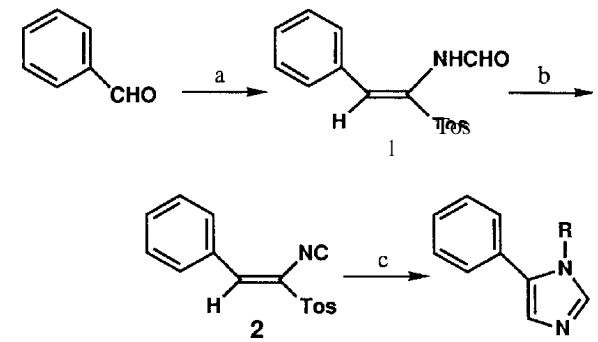

(B)

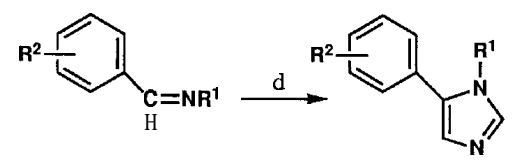

Reagent: (a) TosMIC, $\mathrm{KO}^{\mathrm{t}} \mathrm{Bu}, \mathrm{DME}$ (b) $\mathrm{POCl}_{3}, \mathrm{NEt}_{3}$, DME

(c) $\mathrm{RNH}_{2}, \mathrm{MeOH}$ (d) TosMIC, $\mathrm{K}_{2} \mathrm{CO}_{3}, \mathrm{MeOH}$

\section{1-Ethyl-5-phenylimidazole (3)}

To a solution of $1.5 \mathrm{~g}$ of compound $\mathbf{1}$ in $10 \mathrm{ml}$ of dry 1,2-dimethoxyethane (DME) under $\mathrm{N}_{2}$ was added at $-5^{\circ} \mathrm{C}$ all at once $3.5 \mathrm{ml}$ of triethylamine. To the mixture was added dropwise a solution of $0.5 \mathrm{ml}$ of phosphorus oxychloride in $0.5 \mathrm{ml}$ of DME at $-10-5^{\circ} \mathrm{C}$. After stirring for $1 \mathrm{hr}$ at $0^{\circ} \mathrm{C}$, the mixture was poured into $200 \mathrm{ml}$ of icewater and extracted with dichloromethame. The dichloromethane solution was washed with brine, dried over $\mathrm{Na}_{2} \mathrm{SO}_{4}$, and concentrated under reduced pressure. To the residue (crude compound 2) was added a mixture of $1.3 \mathrm{~g}$ of ethylamine hydrochloride and $2.1 \mathrm{ml}$ of triethylamine in $10 \mathrm{ml}$ of methanol, which had been stirred for $12 \mathrm{hr}$ at room temperature. After stirring for $24 \mathrm{hr}$ at room temperature, the mixture was concentrated under reduced pressure and the product was extracted with dichloromethane. The dichloromethane solution was washed with brine, dried over $\mathrm{Na}_{2} \mathrm{SO}_{4}$ and concentrated. The residue was chromatographed on silica gel and eluted with ethyl acetate-hexane $(1: 2),(1: 1),(1: 2)$ and $2 \%$ isopropyl alcohol in ethyl acetate. Concentration of the eluate of $2 \%$ isopropyl alcohol in ethyl acetate under reduced pressure afforded $0.31 \mathrm{~g}(38 \%)$ of 3 . NMR $\delta: 1.34(3 \mathrm{H}, \mathrm{t}, J=8 \mathrm{~Hz}), 4.02(2 \mathrm{H}, \mathrm{q}, J=8$ $\mathrm{Hz}), 7.08(1 \mathrm{H}, \mathrm{s}), 7.20-7.54(5 \mathrm{H}, \mathrm{m}), 7.60(1 \mathrm{H}, \mathrm{s})$. Anal. Found: C, 59.45 ; H, 5.34 ; N, 10.71. Calcd. for $\mathrm{C}_{13} \mathrm{H}_{14} \mathrm{~N}_{2} \mathrm{O}_{4}$ (oxalate salt) : C, $59.54 ; \mathrm{H}, 5.38 ; \mathrm{N}, 10.68 \%$.

Compounds 4, 7 and 9 were prepared in the same manner as compound 3 with use of propylamine, cyclohexylamine and 1-aminomethylnaphthalene, respectively, instead of ethylamine. Yield was calculated based on compound $\mathbf{1}$.

5-Phenyl-1-propylimidazole (4) Yield 53\%. NMR $\delta: 0.84(3 \mathrm{H}, \mathrm{t}, J=8 \mathrm{~Hz}), 1.4-1.9$ $(2 \mathrm{H}, \mathrm{m}), 3.96(2 \mathrm{H}, \mathrm{t}, J=8 \mathrm{~Hz}), 6.90-7.80(7 \mathrm{H}, \mathrm{m})$. Anal. Found: C, 60.59 ; H, 5.84 ; N, 9.89. Calcd. for $\mathrm{C}_{14} \mathrm{H}_{16} \mathrm{~N}_{2} \mathrm{O}_{4}$ (oxalate salt) : C, $60.86 ; \mathrm{H}, 5.83 ; \mathrm{N}, 10.14 \%$.

1-Cyclohexyl-5-phenylimidazole (7) Yield 53\%. NMR $\delta: 0.90-2.24(10 \mathrm{H}, \mathrm{m}), 3.62-$ $4.14(1 \mathrm{H}, \mathrm{m}), 7.04(1 \mathrm{H}, \mathrm{s}), 7.20-7.60(5 \mathrm{H}, \mathrm{m}), 7.70(1 \mathrm{H}, \mathrm{s})$. Anal. Found: C, 64.36 ; H, 6.33 ; N, 8.85. Calcd. for $\mathrm{C}_{17} \mathrm{H}_{20} \mathrm{~N}_{2} \mathrm{O}_{4}$ (oxalate salt) : C, $64.54 ; \mathrm{H}, 6.37 ; \mathrm{N}, 8.86 \%$. 
1 -(1-Naphthylmethyl)-5 - phenylimidazole (9) Yield 32\%. NMR $\delta: 5.62(2 \mathrm{H}, \mathrm{s})$, 6.94- 8.04 (12H, m). Anal. Found : C, $70.53 ; \mathrm{H}, 4.78$ N, 7.49. Calcd. for $\mathrm{C}_{22} \mathrm{H}_{18} \mathrm{~N}_{2} \mathrm{O}_{4}$ (oxalate salt) : C, $70.58 ; \mathrm{H}, 4.85 ; \mathrm{N}, 7.48 \%$.

1-Butyl-5-phenylimidazole (5) and 1-phenethyl-5-phenylimidazole (6) we r e synthesized according to the procedure reported priviously (Kikuchi et al., 1990).

1,5-Diphenylimidazole (8)

A mixture of $1.0 \mathrm{~g}$ of benzaldehyde, $0.90 \mathrm{~g}$ of aniline and $3.0 \mathrm{~g}$ of anhydrous $\mathrm{MgSO}_{4}$ in $20 \mathrm{ml}$ of dichloromethane was refluxed for $2 \mathrm{hr}$. $\mathrm{MgSO}_{4}$ was filtered off and the filtrate was concentrated under reduced pressure. The residue was dissolved in $20 \mathrm{ml}$ of methanol, and to the mixture was added $2.5 \mathrm{~g}$ of tosylmethylisocyanide (TosMIC) and $4 \mathrm{~g}$ of anhydrous $\mathrm{K}_{2} \mathrm{CO}_{3}$. After refluxing for $2.5 \mathrm{hr}$, the solvent was evaporated and $100 \mathrm{ml}$ of water was added to the residue. The product was extracted with ethyl acetate and the ethyl acetate solution was washed with brine, dried over $\mathrm{Na}_{2} \mathrm{SO}_{4}$ and concentrated. The residue was chromatographed on silica gel by elution with hexaneethyl acetate $(3: 1)$ and $(1: 1)$. Concentration of the hexane-ethyl acetate $(1: 1)$ eluate under reduced pressure followed by recrystallization from ethanol and water afforded $0.23 \mathrm{~g}(10 \%)$ of $8, \mathrm{mp} 126-128^{\circ} \mathrm{C}$. NMR 6: 7.00-7.54 $(11 \mathrm{H}, \mathrm{m}), 7.72(1 \mathrm{H}, \mathrm{s})$. Anal. Found : C, 81.59; H, 5.43 ; N, 12.67. Calcd. for $\mathrm{C}_{15} \mathrm{H}_{12} \mathrm{~N}_{2} \mathrm{O}: \mathrm{C}, 81.79 ; \mathrm{H}, 5.49 ; \mathrm{N}, 12.72 \%$. 1-(2-Naphthylmethyl)imidazole ( 10$)$

To a suspension of $0.54 \mathrm{~g}$ of sodium hydride $(60 \%$ in oil) in $10 \mathrm{ml}$ of dimethylformamide was added $0.54 \mathrm{~g}$ of imidazole at $0-5^{\circ} \mathrm{C}$, and the mixture was stirred for $1 \mathrm{hr}$ at room temperature. To the mixture was added $2.0 \mathrm{~g}$ of 2-(bromomethyl)naphthalene. After stirring for $15 \mathrm{hr}$ at toom temperature, to the mixture was added $50 \mathrm{ml}$ of water, and the product was extracted with ether. The ether solution was washed with 5\% $\mathrm{NaOH}$ solution, brine, and dried over $\mathrm{Na}_{2} \mathrm{SO}_{4}$. Evaporation of the solvent followed by recrystallization from isopropyl ether to yield $1.1 \mathrm{~g}(61 \%)$ of $10, \mathrm{mp} 88^{-9}-90^{\circ} \mathrm{C}$. NMR $\delta$ : $5.28(2 \mathrm{H}, \mathrm{s}), 6.86-8.04(10 \mathrm{H}, \mathrm{m})$. Anal. Found: C, $80.82 ; \mathrm{H}, 5.79 ; \mathbf{N}, 13.49$. Calcd. for $\mathrm{C}_{14} \mathrm{H}_{12} \mathrm{~N}_{2}: \mathrm{C}, 80.74 ; \mathrm{H}, 5.81 ; \mathrm{N}, 13.45 \%$.

1-Ethyl-5-(4-hydroxyphenyl)imidazoZe (11)

A mixture of $1.6 \mathrm{~g}$ of ethylamine hydrochloride, $3.3 \mathrm{ml}$ of triethylamine and $6.0 \mathrm{~g}$ of $\mathrm{MgSO}_{4}$ was stirred for $1 \mathrm{hr}$ at room temperature. To the mixture was added $2.4 \mathrm{~g}$ of 4-hydroxybenzaldehyde and refluxed for $2 \mathrm{hr}$. After removal of $\mathrm{MgSO}_{4}$ by filtration, the filtrate was concentrated under reduced pressure. To the residue dissolved in $30 \mathrm{ml}$ of methanol was added $5.0 \mathrm{~g}$ of TosMIC and $8.0 \mathrm{~g}$ of $\mathrm{K}_{2} \mathrm{CO}_{3}$, and the mixture was refluxed for $2 \mathrm{hr}$. After concentration of the solvent, the product was extracted with ethyl acetate and the ethyl acetate solution was washed with brine, dried over $\mathrm{Na}_{2} \mathrm{SO}_{4}$, and concentrated. The residue was chromatographed on silica gel and eluted with hexane-ethyl acetate $(3: 1)$ and $3 \%$ isopropyl alcohol in ethyl acetate. Concentration of the eluate of $3 \%$ isopropyl alcohol in ethyl acetate followed by recrystallization from ethanol and water to give $1.1 \mathrm{~g}(30 \%)$ of $\mathbf{1 1}, \mathrm{mp} 152-154^{\circ} \mathrm{C}$. NMR $\delta: 1.36(3 \mathrm{H}, \mathrm{t}$, $J=8 \mathrm{~Hz}), 4.02(2 \mathrm{H}, \mathrm{q}, J=8 \mathrm{~Hz}), 7.00(2 \mathrm{H}, \mathrm{d}, J=8 \mathrm{~Hz}), 7.04(1 \mathrm{H}, \mathrm{s}), 7.24(2 \mathrm{H}, \mathrm{d}, J=8 \mathrm{~Hz})$, $7.65\left(1 \mathrm{H}\right.$, s). Anal. Found: C, $70.21 ; \mathrm{H}, 6.40 ; \mathrm{N}, 14.83$. Calcd. for $\mathrm{C}_{11} \mathrm{H}_{12} \mathrm{~N}_{2} \mathrm{O}: \mathrm{C}$, $70.19 ; \mathrm{H}, 6.43 ; \mathrm{N}, 14.88 \%$.

Compounds 12-18 were prepared in the same manner as compound 11 , but with the use of the appropriate amine, instead of ethylamine. Yield was calculated based on 4-hydroxybenzaldehyde. 
1-Butyl-5-(4-hydroxyphenyl)imidazole(12) Yield 75\%. mp 161-164 ${ }^{\circ} \mathrm{C}$. NMR $\delta$ : $0.86(3 \mathrm{H}, \mathrm{t}, J=7 \mathrm{~Hz}), 1.02-1.80(4 \mathrm{H}, \mathrm{m}), 3.94(2 \mathrm{H}, \mathrm{t}, J=8 \mathrm{~Hz}), 6.80-7.30(5 \mathrm{H}, \mathrm{m}), 7.64(1 \mathrm{H}$, s). Anal. Found : C, $72.24 ; \mathrm{H}, 7.40 ; \mathrm{N}, 12.87$. Calcd. for $\mathrm{C}_{13} \mathrm{H}_{16} \mathrm{~N}_{2} \mathrm{O}: \mathrm{C}, 72.19 ; \mathrm{H}, 7.46$; $\mathrm{N}, 12.95 \%$.

1-Hexyl-5-(4-hydroxyphenyl)imidazole (13) Yield 77\%. mp 117-119 ${ }^{\circ} \mathrm{C}$. NMR $\delta$ : $0.82(3 \mathrm{H}, \mathrm{t}, J=7 \mathrm{~Hz}), 1.00-1.40(6 \mathrm{H}, \mathrm{m}), 1.62(2 \mathrm{H}, \mathrm{m}), 3.92(2 \mathrm{H}, \mathrm{t}, J=8 \mathrm{~Hz}), 6.93-7.28(6 \mathrm{H}$, $\mathrm{m}), 7.63(1 \mathrm{H}, \mathrm{s})$.

5-(4-Hydroxyphenyl)-1-octylimidazole (14) Yield 77\%. mp 96-97 ${ }^{\circ}$. NMR $\delta:$ $0.86(3 \mathrm{H}$, deformed t), 1.00-1.84 (12H, m), $3.96(2 \mathrm{H}, \mathrm{t}, J=8 \mathrm{~Hz}), 6.80-7.26(6 \mathrm{H}, \mathrm{m}), 7.64$ $(1 \mathrm{H}, \mathrm{s})$. Anal. Found: $\mathrm{C}, 74.60 ; \mathrm{H}, 8.86 ; \mathrm{N}, 10.31$. Calcd. for $\mathrm{C}_{17} \mathrm{H}_{24} \mathrm{~N}_{2} \mathrm{O}: \mathrm{C}, 74.96 ; \mathrm{H}$, $8.88 ; \mathrm{N}, 10.28 \%$.

1-Decyl-5-(4-hydroxyphenyl)imidazole (15) Yield 72\%. mp 87-90 ${ }^{\circ} \mathrm{C}$. NMR $\delta$ : $0.86(3 \mathrm{H}$, deformed t), 1.00-1.80 $(16 \mathrm{H}, \mathrm{m}), 3.94(2 \mathrm{H}, \mathrm{t}, J=8 \mathrm{~Hz}), 6.80-7.30(6 \mathrm{H}, \mathrm{m}), 7.64$ $(1 \mathrm{H}, \mathrm{s})$. Anal. Found: C, 76.04 ; H, 9.39 ; N, 9.47. Calcd. for $\mathrm{C}_{19} \mathrm{H}_{28} \mathrm{~N}_{2} \mathrm{O}$ : C, 75.96 ; $\mathrm{H}$, $9.39 ; \mathrm{N}, 9.32 \%$.

1-Geranyl-5-(4-hydroxyphenyl)imidazole (16) Yield 89\%. mp 96-99 ${ }^{\circ} \mathrm{C}$. NMR $\delta$ : $1.58(3 \mathrm{H}$, broad s), $1.63(3 \mathrm{H}$, broad s), $1.67(3 \mathrm{H}$, broad s $), 1.80-2.20(4 \mathrm{H}, \mathrm{m}), 4.50(2 \mathrm{H}, \mathrm{d}$, $J=7 \mathrm{~Hz}), 4.88-5.16(1 \mathrm{H}, \mathrm{m}), 5.16-5.44(1 \mathrm{H}, \mathrm{m}), 6.80-7.10(3 \mathrm{H}, \mathrm{m}), 7.25(2 \mathrm{H}, \mathrm{d}, J=8 \mathrm{~Hz})$, $7.63(1 \mathrm{H}, \mathrm{s})$. Anal. Found: C, $76.75 ; \mathrm{H}, 8.20 ; \mathrm{N}, 9.41$. Calcd. for $\mathrm{C}_{19} \mathrm{H}_{24} \mathrm{~N}_{2} \mathrm{O}: \mathrm{C}, 76.99$; $\mathrm{H}, 8.16 ; \mathrm{N}, 9.45 \%$.

1-Cyclohexylmethyl-5-(4-hydroxyphenyl)imidazole (I 7) Yield 50\%. mp $184-186^{\circ} \mathrm{C}$. NMR $\delta: 0.52-1.80(11 \mathrm{H}, \mathrm{m}), 3.78(2 \mathrm{H}, \mathrm{d}, J=8 \mathrm{~Hz}), 6.80-7.05(3 \mathrm{H}, \mathrm{m}), 7.24(2 \mathrm{H}, \mathrm{d}, J=12$ $\mathrm{Hz}), 7.58(1 \mathrm{H}, \mathrm{s})$. Anal. Found : C, $75.11 ; \mathrm{H}, 7.88 ; \mathrm{N}, 10.85$. Calcd. for $\mathrm{C}_{16} \mathrm{H}_{20} \mathrm{~N}_{2} \mathrm{O}: \mathrm{C}$, 74.97 ; H, $7.86 ; \mathrm{H}, 10.93 \%$.

5-(4-Hydroxyphenyl)-1-(1-naphthylmethyl)imidazole (18) Yield 2\%. mp 246-248 “C. NMR (DMSO-d,) $\delta: 5.62(2 \mathrm{H}, \mathrm{s}), 6.40-8.20(11 \mathrm{H}, \mathrm{m}), 9.44(1 \mathrm{H}, \mathrm{s})$. Anal. Found : C, $79.88 ; \mathrm{H}, 5.39 ; \mathrm{N}, 9.11$. Calcd. for $\mathrm{C}_{20} \mathrm{H}_{16} \mathrm{~N}_{2} \mathrm{O}: \mathrm{C}, 79.98 ; \mathrm{H}, 5.37 ; \mathrm{N}, 9.33 \%$.

1-Ethyl-5-(4-methoxyphenyl)imidazole (19)

To a suspension of $0.10 \mathrm{~g}$ of sodium hydride ( $60 \%$ in oil) in $10 \mathrm{ml}$ of dimethylform. amide was added $0.40 \mathrm{~g}$ of compound 11, and the mixture was stirred for $1 \mathrm{hr}$ at room temperature. To the ice-cooled mixture was added dropwise $0.14 \mathrm{ml}$ of methyl iodide. After stirring for $15 \mathrm{hr}$ at room temperature, $50 \mathrm{ml}$ of water was added to the mixture, and the product was extracted with ether. The ether solution was washed with $5 \%$ $\mathrm{NaOH}$ solution and brine, and dried over $\mathrm{Na}_{2} \mathrm{SO}_{4}$. After removal of the solvent, the residue was chromatographed on silica gel by elution with hexane-ethyl acetate $(3: 1)$ and ethyl acetate. Concentration of ethyl acetate eluate under reduced pressure afforded $0.35 \mathrm{~g}(83 \%)$ of 19. NMR $\delta: 1.32(3 \mathrm{H}, \mathrm{t}, J=7 \mathrm{~Hz}), 3.88(3 \mathrm{H}, \mathrm{s}), 4.00(2 \mathrm{H}, \mathrm{d}, J=$ $7 \mathrm{~Hz}), 6.80-7.14(3 \mathrm{H}, \mathrm{m}), 7.34(2 \mathrm{H}, \mathrm{d}, J=8 \mathrm{~Hz}), 7.58(1 \mathrm{H}, \mathrm{s})$. Anal. Found: $\mathrm{C}, 57.22 ; \mathrm{H}$, $5.48 ; \mathrm{N}, 9.54$. Calcd. for $\mathrm{C}_{14} \mathrm{H}_{16} \mathrm{~N}_{2} \mathrm{O}_{5}$ (oxalate salt) : C, $57.53 ; \mathrm{H}, 5.52 ; \mathrm{N}, 9.58 \%$.

Compounds 20-25 were prepared in an analogous manner to that described for $\mathbf{1 9}$. Yield was calculated based on each 1-alkyl-5-(4-hydroxyphenyl)imidazole.

1-Butyl-5-(4-methoxyphenyl)imidazole (20) Yield 92\%. NMR $\delta: 0.84(3 \mathrm{H}, \mathrm{t}, J=$ $8 \mathrm{~Hz}), 1.00-1.80(4 \mathrm{H}, \mathrm{m}), 3.87(3 \mathrm{H}, \mathrm{s}), 3.93(2 \mathrm{H}, \mathrm{d}, J=8 \mathrm{~Hz}), 6.80-7.10(3 \mathrm{H}, \mathrm{m}), 7.32(2 \mathrm{H}$, $\mathrm{d}, J=8 \mathrm{~Hz}), 7.56(1 \mathrm{H}, \mathrm{s})$. Anal. Found : C, $72.61 ; \mathrm{H}, 7.83$; N, 11.99. Calcd. for $\mathrm{C}_{14} \mathrm{H}_{18} \mathrm{~N}_{2} \mathrm{O}: \mathbf{C}, 73.01 ; \mathrm{H}, 7.88 ; \mathrm{N}, 12.16 \%$.

1-Hexyl-5-(4-methoxyphenyl)imidazole $(21)$ Yield 44\%. NMR $\delta: 0.83(3 \mathrm{H}, \mathrm{t}, J=$ 
$7 \mathrm{~Hz}, 1.08-1.32(6 \mathrm{H}, \mathrm{m}), 1.59(2 \mathrm{H}, \mathrm{m}), 3.84(3 \mathrm{H}, \mathrm{s}), 3.90(2 \mathrm{H}, \mathrm{t}, J=7 \mathrm{~Hz}), 6.89-7.31(5 \mathrm{H}$, $\mathrm{m}), 7.52(1 \mathrm{H}, \mathrm{s})$.

5-(4-Methoxyphenyl)-1-octylimidazole (22) Yield 89\%. NMR $\delta: 0.85(3 \mathrm{H}$, deformed t), 1.00-1.80 (12H, m), $3.86(3 \mathrm{H}, \mathrm{s}), 3.92(2 \mathrm{H}, \mathrm{t}, J=7 \mathrm{~Hz}), 6.80-7.44(5 \mathrm{H}, \mathrm{m}) .7 .56$ $(1 \mathrm{H}, \mathrm{s})$. Anal. Found: $\mathrm{C}, 75.09 ; \mathrm{H}, 9.10 ; \mathrm{N}, 9.67$. Calcd. for $\mathrm{C}_{18} \mathrm{H}_{26} \mathrm{~N}_{2} \mathrm{O}: \mathrm{C}, 75.48 ; \mathrm{H}$, $9.15 ; \mathrm{N}, 9.78 \%$.

1-Decyl-5-(4-methoxyphenyl)imidazole (23) Yield 88\%. NMR $\delta: 0.88(3 \mathrm{H}$, deformed t), 1.00-1.80 (16H, m), $3.88(3 \mathrm{H}, \mathrm{s}), 3.94(2 \mathrm{H}, \mathrm{t}, J=7 \mathrm{~Hz}), 6.80-7.44(5 \mathrm{H}, \mathrm{m}), 7.54$ $(1 \mathrm{H}, \mathrm{s})$. Anal. Found: $\mathrm{C}, 75.97 ; \mathrm{H}, 9.52 ; \mathrm{N}, 8.71$. Calcd. for $\mathrm{C}_{20} \mathrm{H}_{30} \mathrm{~N}_{2} \mathrm{O}: \mathrm{C}, 76.39 ; \mathrm{H}$, $9.62 ; \mathrm{N}, 8.91 \%$.

1-Geranyl-5-(4-methoxyphenyl)imidazole (24) Yield 67\%. NMR $\delta: 1.30-2.30$ $(13 \mathrm{H}, \mathrm{m}), 3.86(3 \mathrm{H}, \mathrm{s}), 4.48(2 \mathrm{H}, \mathrm{d}, J=6 \mathrm{~Hz}), 4.80-5.45(2 \mathrm{H}, \mathrm{m}), 6.84-7.44(5 \mathrm{H}, \mathrm{m}), 7.56(1 \mathrm{H}$, s).

1-Cyclohexylmethyl-5-(4-methoxyphenyl)imidazole (25) Yield $85 \%$. mp $63-65^{\circ} \mathrm{C}$ (recrystallized from hexane). NMR $\delta: 0.44-1.84(11 \mathrm{H}, \mathrm{m}), 3.76(2 \mathrm{H}, \mathrm{d}, J=7 \mathrm{~Hz}), 3.87$ $(3 \mathrm{H}, \mathrm{s}), 6.80-7.04(3 \mathrm{H}, \mathrm{m}), 7.16-7.40(2 \mathrm{H}, \mathrm{m}), 7.52(1 \mathrm{H}, \mathrm{s})$. Anal. Found: C, 75.46 ; H, 8.18 ; $\mathrm{N}, 10.26$. Calcd. for $\mathrm{C}_{17} \mathrm{H}_{22} \mathrm{~N}_{2} \mathrm{O}: \mathrm{C}, 75.52 ; \mathrm{H}, 8.20 ; \mathrm{N}, 10.36 \%$.

\section{Lettuce and rice seedling tests}

Lettuce (Lactuca sativa L. cv. Sacramento) seedling tests were performed by the same method as described previously (Kikuchi et al., 1990). The effects of the compounds on the growth of rice (Oryza sativa L. cv. nihonbare) seedlings were examined according to the method as previously reported by Ogasawara et al. (1990). Rice seeds were sterilized with $1 \%$ sodium hypochlorite solution at $25^{-}-30^{\circ} \mathrm{C}$ for $0.5 \mathrm{hr}$, and were germinated in deionized water for 2 days at $30^{\circ} \mathrm{C}$ in the dark. Eight germinated seeds with uniformed-sized coleoptiles were set in four slits $(3.0 \times 0.25 \mathrm{~cm})$ of a polystyrene disc ( $5 \mathrm{~cm}$ diameter $\times 0.3 \mathrm{~cm}$ thickness), which was floated on $200 \mathrm{ml}$ of deionized water containing each compound dissolved in dimethyl sulfoxide $(0.4 \mathrm{ml})$ in a conical beaker $\left(11 \mathrm{~cm}\right.$ height). Plants were maintained at $30 \pm 1{ }^{\circ} \mathrm{C}$ in darkness (relative humidity; $60 \pm 5 \%$ ) or in light (photosynthetically available radiation ; 250 $\mu \mathrm{mol} \cdot \mathrm{m}^{-2} \cdot \mathrm{sec}^{-1}$, photoperiod ; $12 \mathrm{hr}$, relative humidity ; $70 \pm 5 \%$ ). The growth regulatory activity of the compounds was evaluated after 3 (in darkness) or 4 (in light) days by inspecting the rate of growth inhibition or stimulation of the hypocotyls and radicles. The rates were determined by percentage of the averaged lengths of hypocotyls or radicles of treated plants to those of controls and indicated according to the following scale :

Inhibition

$$
0 \leq 10 \%<-1 \leq 30 \%<-2 \leq 50 \%<-3 \leq 70 \%<-4 \leq 90 \%<-5
$$

stimulation

$$
0 \leq 10 \%<1 \leq 30 \%<2 \leq 50 \% \leq 3 \leq 70 \%<4 \leq 90 \%<5
$$

\section{RESULTS AND DISCUSSIONS}

\section{Synthesis}

1,5-Disubstituted imidazoles were synthesized by two different procedures using tosylmethylisocyanide (TosMIC) according to the methods described by van Leusen et 
al. (1977, 1979) (Scheme 1). (Method A) 1-Isocyano-2-phenyl-1-tosylethene (2) was treated with an appropriate amine to afford 1-alkyl-5-phenylimidazoles. (Method B) Cyclization of aldimines derived from benzaldehydes and amines with TosMIC in the presence of potassium carbonate in methanol yielded 1,5-disubstituted imidazoles. In method B 1-alkyl-5-(4-hydroxyphenyl)imidazoles were obtained relatively high yield. Methylation of 4-hydroxy group on the benzene ring by methyl iodide gave 1-alkyl5-(4-methoxypheny1)imidazoles.

\section{Biological activities}

Table 1 shows the effects of a large number of 1,5-disubstituted imidazoles on the growth of lettuce seedlings. In a series of 1-substituted 5-phenylimidazoles, the 1ethyl(3), the 1-cyclohexyl (7) and the 1-(1-naphthylmethyl) (9) analogs inhibited considerably the hypocotyl growth of lettuce seedlings at $10 \mathrm{ppm}$. However, those activities were somewhat lower compared with those of the l-butyl (5) and the I-phenethyl (6) nalogs which had been reported previously (Kikuchi et al., 1990). 1-(2-Naphthylmethyl)imidazole (10) showed very low activity and imidazole had no activity at $10 \mathrm{ppm}$, suggesting that the presence of two substituents at the 1-and 5-positions of the imidazole ring is essential for the inhibitory activity in hypocotyl growth.

The introduction of a hydroxy substituent into the phenyl group at the 5-position decreased the activity in comparison with those of the corresponding 1-substituted 5phenylimidazoles (compounds 11, 12 and 18). Other 5-(4-hydroxyphenyl)imidazoles also showed very weak activity irrespective of the substituent at the 1-position (compounds 13-17). On the other hand, in a series of 5-(4-methoxyphenyl)imidazoles

Table 1. Effects of 1,5-disubstituted imidazoles on the growth of lettuce seedlings

\begin{tabular}{|c|c|c|c|c|}
\hline \multirow[b]{2}{*}{ No } & \multirow[b]{2}{*}{$\mathrm{R}^{5}$} & \multirow[b]{2}{*}{$\mathrm{R}^{1}$} & \multicolumn{2}{|c|}{ Activity (10 ppm) } \\
\hline & & & Hypocotyl & Root \\
\hline & $\mathrm{H}$ & $\mathrm{H}$ & 0 & -1 \\
\hline 3 & phenyl & ethyl & -3 & -1 \\
\hline & & cyclohexyl & -3 & 0 \\
\hline 8 & 光 & phenyl & -2 & 0 \\
\hline 9 & "1 & 1-naphthylmethyl & -3 & -3 \\
\hline 10 & $\mathrm{H}$ & 2-naphthylmethyl & -1 & -2 \\
\hline 11 & 4-hydroxyphenyl & ethyl & -1 & 0 \\
\hline 12 & & n-butyl & -1 & 1 \\
\hline 13 & m & n-hexyl & -1 & 1 \\
\hline 14 & & n-octyl & -1 & 1 \\
\hline 15 & & $\mathrm{n}$-decyl & -1 & 1 \\
\hline 16 & & geranyl & 0 & -1 \\
\hline 17 & 1) & cyclohexylmethyl & -2 & 2 \\
\hline 18 & $n$ & l-naphthylmethyl & 0 & -1 \\
\hline 19 & 4-methoxyphenyl & ethyl & -2 & 0 \\
\hline 20 & $n$ & n-butyl & -4 & -1 \\
\hline 21 & & n-hexyl & -3 & \\
\hline 22 & $n$ & n-octyl & -2 & 0 \\
\hline 23 & $\eta$ & n-decyl & -1 & -1 \\
\hline 24 & & geranyl & -1 & 1 \\
\hline 25 & & cyclohexylmethyl & -4 & -1 \\
\hline
\end{tabular}


the 1-butyl (20) and the 1-cyclohexylmethyl (25) analogs exhibited high inhibitory activity, which was comparable to those of the most active compounds reported previously (Kikuchi et al., 1990). Increasing the size of the alkyl substituent at the 1-position led to reduced activity (compounds 21, 24).

As previously described (Kikuchi et al., 1990), several 1-alkyl-5-arylimidazoles such as compound 5 have been found to promote the root growth in the lettuce seedlings. However, a series of compounds shown in Table 1 did not show distinct promoting effects on the root growth in the lettuce seedlings. We used a new bioassay method recently developed by Ogasawara et al . (1990) in order to examine the effects of 1,5-disubstituted imidazoles on the growth of rice seedlings. This method was more suitable than a Petri dish method to evaluate the elongation of rice roots (Fig. 1).

It is well known that light affects the growth of roots (Beffa et al., 1982). We first examined the light effects on the action of the substituted imidazoles. Fig. 2 shows the effects of 1-phenethyl-5-phenylimidazole (6) on the growth of rice seedlings in light and darkness. In light compound 6 promoted the growth of root at a low concentration of $0.1 \mathrm{ppm}$, whereas in darkness it showed slightly inhibitory activity at the same concentration. No effect was found on the growth of leaf sheath at the concentrations causing the promotion of roots. At high concentrations of $10-50 \mathrm{ppm}$ the growth of root and leaf sheath was inhibited both in dark and light. Since the stimulation of the root growth was observed by treatment of compound 6 in light, in further experiment we examined structure-activity relationships of a number of 1,5-disubstituted imidazoles under the light.

In Table 2 there are presented the effects of 1,5-disubstituted imidazoles on the growth of rice seedlings. Most of the compounds promoted the growth of roots at the

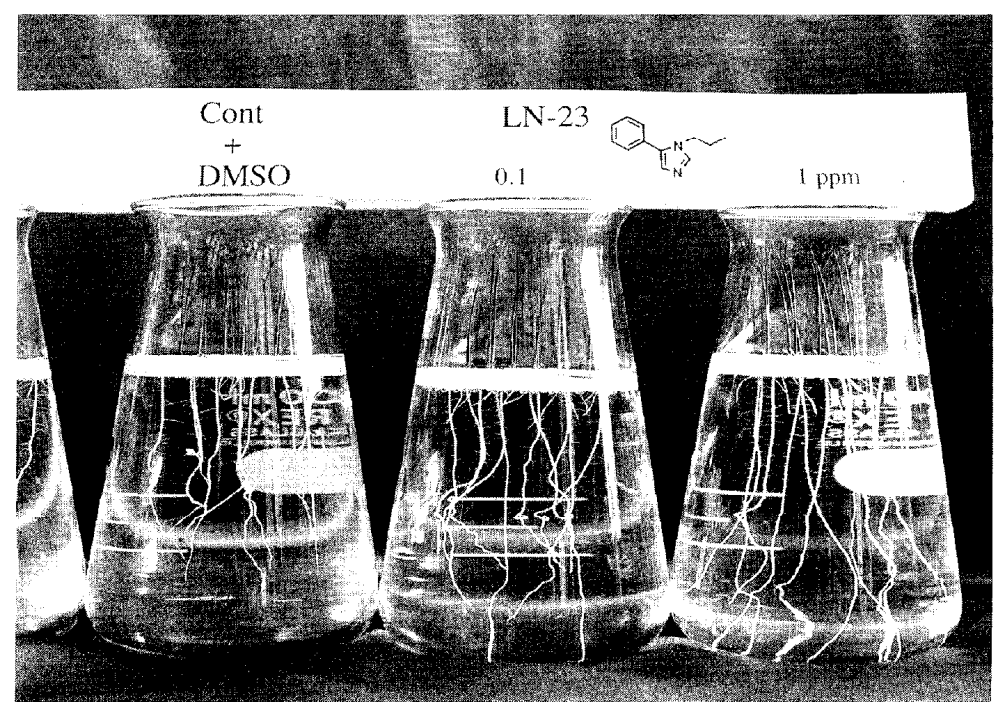

Fig. 1. Rice seedling test : (left) control, (middle, right) treated with 5 phenyl-1-propylimidazole at 0.1 and $1 \mathrm{ppm}$, respectively. 
(A)

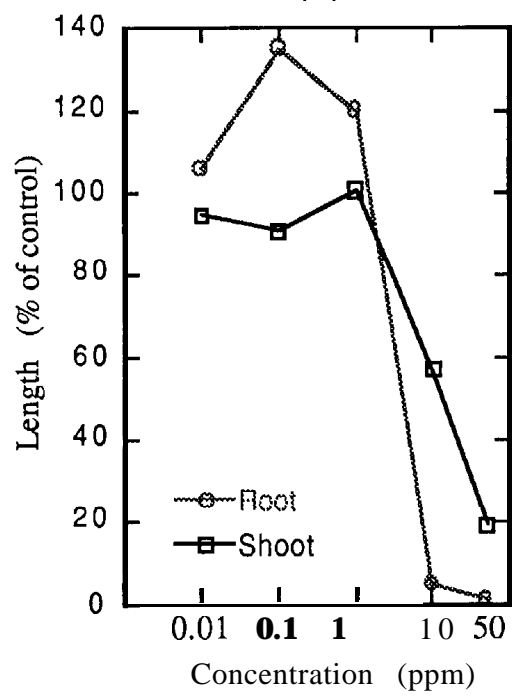

(B)

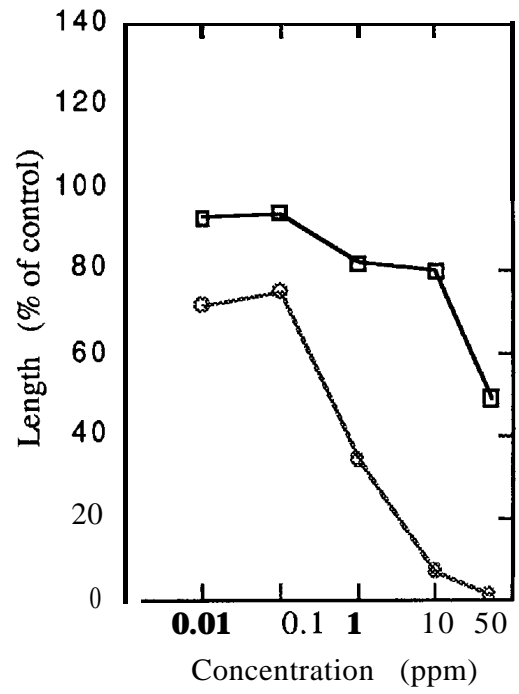

Fig. 2. Effects of 1-phenethyl-5-phenylimidazole on the growth of rice seedlings in light (A) and darkness (B).

Table 2. Effects of 1,5-disubstituted imidazoles on the growth of rice seedlings

\begin{tabular}{|c|c|c|c|c|}
\hline \multirow[b]{3}{*}{ Compound } & \multicolumn{4}{|c|}{ Activity } \\
\hline & conc. (ppm) & 0.1 & \multicolumn{2}{|c|}{1} \\
\hline & $\begin{array}{l}\text { 2nd Leaf } \\
\text { sheath }\end{array}$ & Root & $\begin{array}{l}\text { 2nd Leaf } \\
\text { sheath }\end{array}$ & Root \\
\hline 3 & 0 & 1 & 0 & 1 \\
\hline 4 & 0 & 1 & 0 & 2 \\
\hline 5 & 1 & 2 & 0 & 4 \\
\hline 6 & 0 & 2 & 0 & 1 \\
\hline 7 & 0 & 1 & 0 & 2 \\
\hline 9 & 0 & -1 & -1 & -3 \\
\hline 12 & 0 & 2 & -1 & 0 \\
\hline 14 & 0 & 2 & 0 & 1 \\
\hline 15 & 1 & 2 & 0 & -2 \\
\hline 19 & nt & nt & 1 & 3 \\
\hline 20 & 0 & 3 & 0 & 3 \\
\hline 21 & 0 & 3 & 0 & 1 \\
\hline 22 & 0 & 3 & -1 & 0 \\
\hline 24 & 0 & 2 & -1 & -2 \\
\hline 25 & 0 & 3 & -1 & 2 \\
\hline
\end{tabular}

nt : not tested 
concentration of $0.1-1 \mathrm{ppm}$, but did not show any clear effect on the growth of the shoot at low concentrations (Fig. 3). In the 5-phenylimidazole series, the 1-butyl (5) and the 1-phenethyl (6) analogs stimulated the root growth more than $30 \%$ of the control value at $0.1 \mathrm{ppm}$. The activity of compound 5 increased at $1 \mathrm{ppm}$, whereas that of compound 6 decreased at the same concentration. Of the compounds tested only the 1-naphthylmethyl analog 9 inhibited the growth of roots at 0.1-1 ppm. The compounds having a hydroxy group on the benzene ring $(12,14$ and 15) maintained the stimulating activity at $0.1 \mathrm{ppm}$, however, those activity disappeared at $1 \mathrm{ppm}$. Introduction of a methoxy substituent into the 4-position of the phenyl group (20-25) increased the activity compared with those of the phenyl and the 4-hydroxyphenyl analogs (3-15). These compounds equally promoted the growth of roots at $0.1 \mathrm{ppm}$. However, lengthening an alkyl chain at the 1-position of the imidazole ring decreased the activity at $1 \mathrm{ppm}$. The geranyl analog 24 rather showed inhibitory activity. It is worthy to note that the butyl analog 20 strongly promoted the root growth at relatively wide rage of concentrations (0.1-1 ppm).

It is known that interactions between phytohormones such as indol-3-ylacetic acid and abscisic acid play a major role in the control of root growth (Pilet et al., 1987). However, the precise mechanism of root growth is still uncertain. Compound 20 might offer an effective tool in studies of the mechanism of root growth and also represent a reasonable lead for the development of new plant growth regulators. More detailed investigations on the structure-activity relationships are under way.

\section{REFERENCES}

Beffa, R. and P. E. Pilet 1982 Elongation and gravireaction of intact and segmented root : light

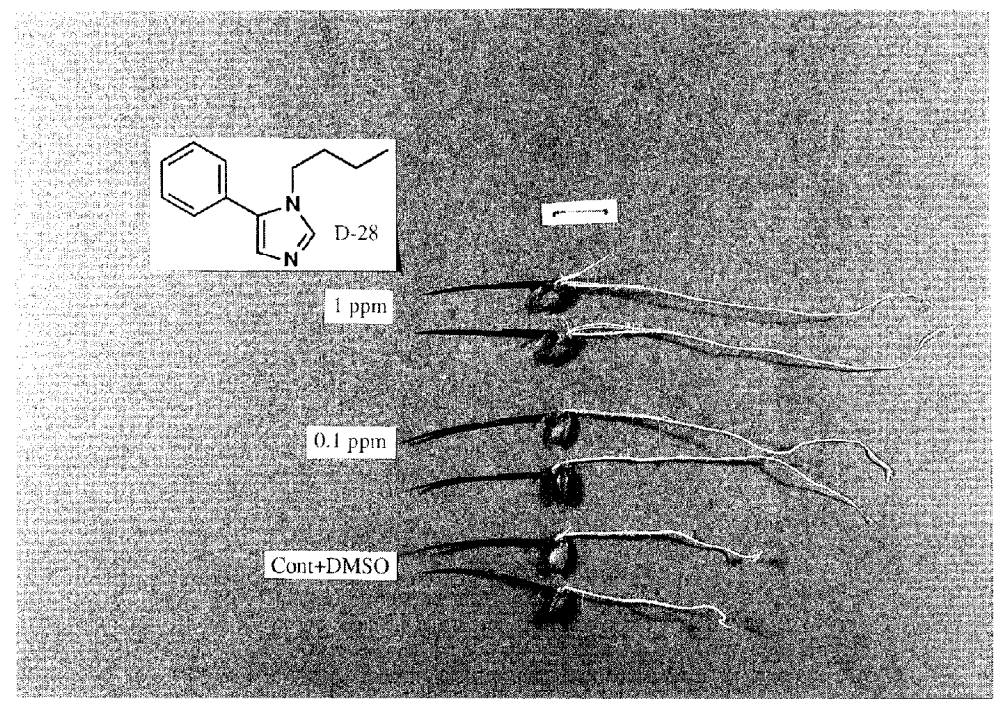

Fig. 3. Rice treated with 1-butyl-Sphenylimidazole at $1 \mathrm{ppm}$ (above), $0.1 \mathrm{ppm}$ (middle) and control (below). 
effects. Physiol. plant., $54: 1-6$

Burden, R. S., D. T. Cooke and G. A. Carter 1989 Inhibitors of sterol biosynthesis and growth in plants and fungi. Phytochemistry, $28: 1791-1804$

Kikuchi, M., E. Kuwano and M. Eto 1990 Synthesis and plant growth regulatory activity of 1,5disubstituted imidazoles. J.Fac. Agr., Kyushu Univ., 34: 397-404

Ogasawara, M., Y. Watanabe, S. Ogawa and M. Konnai 1990 Seminal root elongation test as a new bioassay method for the evaluation of herbicide action. Weed Res., 35:95-101

Pilet, P. E. and M. Saugy 1987 Effect on root growth of endogenous and applied IAA and ABA. Plant Physiol., 83: 33-38

van Leusen, A. M., J. Wildeman and 0. H. Oldenziel 1977 Base-induced cycloaddition of sulfonylmethyl isocyanides to $\mathrm{C}, \mathrm{N}$ double bonds. Synthesis of 1,5-disubstituted and 1,4,5-trisubstituted imidazoles from aldimines and imidoyl chlorides. J. Org. Chem., 42 :1153-1159

van Leusen, A. M., F. J. Schaart and D. van Leusen 1979 Synthesis of 1-isocyano-1-tosyl-1-alkenes and their use in the preparation of imidazoles. Recl.Trav.Chim. Pays-Bas, 98:258-262 